\title{
Detection of antibodies to double stranded DNA and extractable nuclear antigen
}

Immunological abnormalities are a prominent feature of most connective tissue diseases, in particular the presence of autoantibodies to nuclear constituents. Detection of antibodies to nuclear antigens (ANA) by indirect immunofluorescence techniques has become an invaluable screening test in the assessment of patients suspected of having connective tissue diseases. ${ }^{1}$ Recently, different profiles of ANA have been found to characterise different connective tissue diseases (CTD). Laboratory tests for individual ANA reactions have been developed which provide important information for the clinician: these include tests for antibodies to double stranded DNA and to extractable nuclear antigens.

Antibodies to double stranded DNA are found in $60-70 \%$ of patients with active, untreated systemic lupus erythematosus (SLE) and, when present in high titre, show relatively good specificity for the disease. Although the importance of these antibodies is not quite as clearcut as once thought, ${ }^{2}$ their detection is now an established routine laboratory procedure and of undoubted value in assessing a patient suspected of having SLE. A variety of techniques are used but only the most commonly used methods will be described here: for a fuller account, the reader is referred to Stollar. ${ }^{3}$

Tests which detect precipitating antibodies to extractable nuclear antigens are being more widely used in the assessment of patients with connective tissue diseases such as SLE, Sjögren's syndrome, polymyositis and systemic sclerosis. Antibodies can be detected to a large number of saline extractable constituents of mammalian cells. ${ }^{4}$ To date the reactions found most commonly in CTD, and the best characterised, concern antibodies to U1RNP, Sm, Ro(SSA),
La(SSB), Jo-1 and Scl-70. These are highly conserved nuclear or cytoplasmic macromolecules present in a wide range of animal tissues, and the antigenic determinants are expressed in polypeptide components. Jo-1 is expressed on histydyl t RNA synthetase and Scl-70 has been identified as Topoisomerase I. ${ }^{5}$ U1RNP, Sm, Ro and $\mathrm{La}$ are expressed on ribonucleoproteins which seem to have a role in processing, cellular transport, or translation of messenger RNA.

Antibodies to these constituents are found almost exclusively in CTD and have considerable clinical importance. ${ }^{6}$ Antibodies to $\mathrm{Sm}$, Jo-1, and Scl-70, for example, are highly specific for SLE, polymyositis and systemic sclerosis, respectively, and antibodies to Ro and La identify patients with CTD susceptible to developing Sjögren's syndrome.

Anti-Ro is also strongly associated with the development of neonatal lupus and isolated complete heart block. These antibodies identify women with connective tissue diseases most at risk of having babies with these complications. Not all women with antibodies to Ro have affected babies, however, and the degree of risk is not yet known.

Each antibody specificity is found in small subsets of patients with CTD and so to be of help to the clinician the laboratory should be able to detect antibodies to a spectrum of extractable nuclear antigens.

\section{DNA as an antigen}

Natural DNA appears in at least three different forms: a right handed, double stranded (double helix) conformation; a single stranded conformation; and a left handed double stranded conformation (Z-DNA). Although the last of 
these has been identified in a variety of species and may be more naturally antigenic than the other forms, its biological importance is uncertain.

As an antigen, double stranded DNA presents multiple repeating determinants due to its helical arrangement and nucleotide structure. Being polyanionic in nature, it is also an unusual antigen: thus it has a hydrophobic core of stacked heterocyclic bases but has a more soluble repeating sugar-phosphate backbone with acidic phosphate residues. These latter residues make it a very "sticky" antigen. Furthermore, as various serum proteins may bind to DNA, steps should be taken when testing for anti-DNA antibodies to avoid procedures which encourage nonspecific binding.

\section{Measurements of antibodies to double stranded DNA}

Many different methods are available for detecting antibodies to double stranded DNA; of these, the three most widely used methods will be described.

\section{ANTI-DNA ANTIBODIES MEASURED BY RADIOIMMUNOASSAY}

Several commercial kits are now available. We describe the use of one marketed by Amersham International (Amersham, Buckinghamshire) which is based on the ammonium sulphate precipitation assay first described by Farr. ${ }^{7}$ This kit has been available for about 10 years and seems to be widely used. It should, however, be noted that it is not the only commercially available radioimmunoassay for measuring anti-DNA antibodies: Immuno-diagnostics Ltd, Washington, Tyne and Wear have also marketed a kit. Although published comparisons are not available, we found very similar disease specificities for these assays in a study of 130 sera. $^{8}$ The Immuno-diagnostics assay is cheaper; a little over $£ 4$ per sample (allowing for duplicates), compared with just under $£ 5$ per sample for the Amersham kit.

Radioactive DNA is incubated with the patient's serum and ammonium sulphate is used to precipitate immunoglobulin-bound DNA leaving unbound DNA in solution. The DNA used as antigen in the Amersham kit is assessed for double strandedness by chromatography in hydroxy/apatite columns. Although it is claimed that the antigen is pure double stranded DNA, some contamination with single stranded DNA probably also occurs. The level of anti-DNA antibody activity in the serum is expressed as the percentage of the total radioactivity which is precipitated and this is converted by use of a standard curve into so called "Amersham Units".

\section{Apparatus}

1 Fixed or variable micropipettes: volumes $50 \mu \mathrm{l}, 100 \mu \mathrm{l}, 450 \mu \mathrm{l}$;

2 Dispenser 10.0 ml;

3 Vortex mixer;

4 Temperature controlled water baths $56^{\circ} \mathrm{C}$, $37^{\circ} \mathrm{C}$;

5 Refrigerator $4^{\circ} \mathrm{C}$;

6 Centrifuge $(15$ minutes at more than $1000 \mathrm{rpm})$;

7 Gamma scintillation counter;

8 Aluminium foil.

The kits contain the following:

(i) one phial containing $2.4 \mathrm{ml}$ of an aqueous solution of ${ }^{125} \mathrm{I}$-labelled DNA (not more than $\left.2 \mathrm{Ci}, 74 \mathrm{~K} \mathrm{~Bq}{ }^{125} \mathrm{I}\right)$, which has a half life of 60 days;

(ii) one phial of $6 \mathrm{ml}$ ammonium sulphate, which should be cooled to $4^{\circ} \mathrm{C}$ before use;

(iii) four reference standards of freeze dried diluted human SLE serum, containing about $12 \cdot 5 ; 25 ; 50$ and 100 units/ml (phial labels state the exact values);

(iv) one phial of freeze dried buffer (reagent A);

(v) one phial of freeze dried, dilute normal human serum (serum buffer B) for use as a "zero" standard (exact value is stated on the phial label);

(vi) 50 polystyrene assay tubes in a rack;

(vii) Appropriately labelled graph paper for plotting results.

The freeze dried serum phials are reconstituted by adding $200 \mu \mathrm{l}$ distilled water to each phial, replacing the stoppers and allowing the phials to stand for 10 minutes at room temperature. Complete solution should be obtained by gentle mixing. The buffer reagent $A$ and serum buffer $B$ are reconstituted by gentle mixing with $10.0 \mathrm{ml}$ distilled water and allowing to stand for 10 minutes at room temperature.

\section{Assay procedure}

A one in 10 dilution of the test serum is prepared by adding $50 \mu \mathrm{l}$ of serum to $450 \mu \mathrm{l}$ of buffer reagent $\mathrm{A}$. Fifty microlitre aliquots of the stan- 
dard sera and of the diluted unknown sera are aliquoted in duplicate into the tubes provided, which are covered with aluminium foil and incubated in a water bath at $56^{\circ} \mathrm{C}$ for 30 minutes. Heat treatment is used to inactivate $\mathrm{Clq}$, which can bind DNA, so eliminating any non-specific binding proteins. After the tubes are removed from the water bath $50 \mu \mathrm{l}$ of the radiolabelled DNA is added, the tubes vortex mixed for five seconds, covered, and incubated in a $37^{\circ} \mathrm{C}$ water bath for one hour. The tubes are then removed and kept at $4^{\circ} \mathrm{C}$ for $20-24$ hours.

The ammonium sulphate $(100 \mu \mathrm{l})$ is added to the tubes which are then vortex mixed and centrifuged for 15 minutes at $1000 \mathrm{~g}$ at room temperature. The supernatant is aspirated off using a Pasteur pipette attached to a suction pump, carefully avoiding the removal of any precipitate. The radioactivity associated with the precipitates is then counted in a gamma counter $(60$ seconds counting time). A standard curve is constructed by plotting the counts against antiDNA antibody standards, and the values for unknown sera are read off the graph. It may be necessary to dilute the sera, in which case the values are calculated by multiplying the read-off result by the appropriate dilution factor.

As part of their quality assurance programme, Amersham International have informed us that they regularly test interbatch and intrabatch variations. They ensure that standard samples of $10 \mathrm{U} / \mathrm{ml}, 20 \mathrm{U} / \mathrm{ml}$, and $50 \mathrm{U} / \mathrm{ml}$ vary by less than $6 \mathrm{U}, 8 \mathrm{U}$, and $16 \mathrm{U}$, respectively in interbatch testing, and by one third of these figures for intrabatch testing.

\section{ANTI-DNA ANTIBODIES MEASURED BY ELISA}

\section{Apparatus}

1 Ninety six well polystyrene ELISA plates;

2 ELISA reader capable of reading optical densities at $405 / 410 \mathrm{~nm}$.

\section{Reagents and materials}

1 Washing reagents

(i) Phosphate buffered saline (PBS)

$\begin{array}{ll}\mathrm{Na} \mathrm{Cl} & 8.5 \mathrm{~g} \\ \mathrm{Na}_{2} \mathrm{HPO}_{4} & 1.28 \mathrm{~g} \\ \mathrm{NaH}_{2} \mathrm{PO}_{4}, 2 \mathrm{H}_{2} \mathrm{O} & 0.156 \mathrm{~g}\end{array}$

Dissolve in one litre of distilled water and adjust to $\mathrm{pH} 7 \cdot 4-7.6$ with $\mathrm{HCl} / \mathrm{NaOH}$

(ii) PBS Tween 20 (PBS-T)

Make up a solution of $0 \cdot 1 \%(\mathrm{v} / \mathrm{v})$ of
Tween 20 in PBS

2 Solution of $50 \mu \mathrm{g} / \mathrm{ml}$ (in distilled water) of poly L lysine (Sigma, Poole, Dorset).

$32 \%$ solution of casein (BDH, Dagenham, Kent) in PBS to prevent non-specific binding.

4 Double stranded and single stranded DNA For double stranded DNA, treat the calf thymus DNA (Sigma, Poole, Dorset) with $1 \mu \mathrm{g} / \mathrm{ml} \mathrm{S1}$ nuclease (Sigma) for 30 minutes at $37^{\circ} \mathrm{C}$. Single stranded DNA may be prepared by boiling calf thymus for 10 minutes, then cooling on ice for 15 minutes.

5 Second step antibody-for example, alkaline phosphatase conjugated goat antihuman IgG/IgM (Sigma, Poole, Dorset). We typically use a 1/1000 dilution, but the working dilution of each batch of second step antibody must be determined by chequerboard titration.

6 Substrate solution. Prepare p-nitrophenyl phosphate $1 \mathrm{mg} / \mathrm{ml}$ in $0.5 \mathrm{M} \mathrm{NaHCO} ; 2 \mathrm{mM}$ $\mathrm{MgCl}_{2}, \mathrm{pH} 9 \cdot 5$.

\section{Method}

The 96 well polystyrene plates (for example, Immunol 11 Dynatech, Billingshurst, Sussex) are precoated with $50 \mu \mathrm{l}$ of poly L-lysine ando incubated for one hour at $37^{\circ} \mathrm{C}$. Each well iso washed three times with PBS, and $50 \mu$ l of dou $-?$ ble stranded DNA $(10 \mu \mathrm{g} / \mathrm{ml}$ PBS $)$ or single stranded DNA ( $5 \mu \mathrm{g} / \mathrm{ml}$ PBS) added. Although automated washers are available (Dynatech, Billingshurst, Sussex), we use a hand wash bottle called the EIA wash bottle (Ortho, Canada). The plates are incubated overnight at $4^{\circ} \mathrm{C}$ then washed three times with PBS. One hundred $\mu$ l of $2 \%$ casein are added and, after one hour of incubation at $37^{\circ} \mathrm{C}$, three further washes with the PBS-Tween (PBS-T) are performed. Fifty $\mu$ l of diluted (1/200 in PBS-T) test serum samples are added to the wells in duplicate. We use a known high positive sera in quadruplicate, and sera from eight healthy subjects are also included on each plate.

After incubating overnight at $4^{\circ} \mathrm{C}$ the plates are washed three times with PBS-T. Fifty $\mu$ l of alkaline phosphatase conjugated goat antihuman IgM or IgG (diluted 1/100 in PBS-T, $0.5 \%$ casein) are added. Incubation is carried out at $37^{\circ} \mathrm{C}$ for one hour and after washing six times with PBS-T $50 \mu$ l of substrate solution is added. The reaction is allowed to proceed for one hour at $37^{\circ} \mathrm{C}$ and the resulting optical density recorded at A405/410 $\mathrm{nm}$ on the ELISA plate reader. 
The values obtained are expressed as percentages of a known high positive value. As an additional precaution the eight healthy controls are analysed, and the results of the whole plate are accepted only if these control results fall within the normal range (mean $+2 \mathrm{SD}$ ) previously established from a group of 70 normal sera.

Recently, BioHytech (c/o Biological Industries Ltd, Glasgow) have introduced a commercially available anti-DNA antibody ELISA. The principle and steps described in the above assay are much the same as in the BioHytech kit. The kits include 96 well ELISA plates which have single stranded DNA or double stranded DNA already "impregnated" on to the wells. The kits cost about $£ 5$ per sample (allowing for duplicates).

\section{ANTI-DNA ANTIBODIES DETECTED BY}

USING CRITHIDIA LUCILIAE

Crithidia luciliae is a haemoflagellate which is non-pathogenic to man and whose kinetoplast contains helical double stranded DNA not linked to histones.

\section{Apparatus required}

1 Fluorescence microscope (use ultraviolet light at range $320-400 \mathrm{~nm}$ ).

\section{Materials and reagents}

1 Crithidia luciliae fixed to microscope slides (such as Kallestad, c/o Associated Hospital Supply, Pershore, Worcestershire).

2 Fluorosceinated antihuman immunoglobulin (such as, Sigma, Poole, Dorset).

3 Phosphate buffered saline (PBS).

4 Mountant made of glycerine (nine parts) and PBS (one part).

\section{Method}

Test serum is diluted (1/5 as a standard screen, then four-fold dilutions if necessary) in PBS, dropped on the spots of $C$ luciliae and incubated for 15 minutes at room temperature. The slides should be stored at $4^{\circ} \mathrm{C}$ and allowed to reach room temperature immediately before use. After incubation the slides are washed or soaked with PBS for five minutes and then a fluorescent antihuman immunoglobulin (dilution determined by chequerboard titration but typically about $1 / 1000$ ) is added and the slide is reincubated for 15 minutes at room temperature. After a further washing step with PBS the slides are mounted in glycerine and $10 \%$ PBS and examined under the fluorescence microscope.

\section{Notes}

1 Commercial preparations of radiolabelled DNA may contain some denatured DNA. This reduces the specificity of the assay for SLE as antibodies reacting predominantly with determinants on single stranded DNA can be found in rheumatoid arthritis and systemic connective tissue diseases other than SLE.

2 The Farr assay may not detect low avidity anti-DNA antibodies: a second antibody method would be preferable to ammonium sulphate, but is too expensive.

3 The Crithidia luciliae test detects anti-double stranded DNA antibodies of both high and low affinity, but attempts to quantify individual sera are limited to quoting the highest dilution (titre) which gives a positive result.

4 An immunofluorescence technique using human metaphase chromoses as a substrate has been described. ${ }^{9}$ This technique seems to have greater sensitivity than $C$ luciliae while maintaining specificity towards double stranded DNA.

5 An internationally agreed standard (Wo/80) is available from the World Health Organisation but distributed via the Central Laboratory, Netherlands Red Cross Blood Transfusion Service, WHO International Laboratory For Biological Standards, Amsterdam, Holland. Laboratories should calibrate their own standards against $\mathrm{Wo} / 80$ and incorporate them into their chosen assays.

6 In the United Kingdom an External Quality Assessment Scheme for antibodies to double stranded DNA exists (Dr Milford Ward, protein reference unit, immunology department, Royal Hallamshire Hospital, Sheffield).

It must again be stated that the three techniques described are not the only methods of detecting anti-DNA antibodies.

7 Other techniques of detecting anti-DNA antibodies include:

(i) Precipitating assay: performed by double diffusion in dilute agarose gel or counterimmunoelectrophoresis. The former is insensitive and not quantitative; the latter is slightly more sensitive, but results seem to differ from those using other assays.

(ii) Passive haemagglutination: DNA is 
absorbed to tanned or formalised erythrocytes. This assay is sensitive but not specific and requires fresh preparations of coated cells. There is much interassay variability.

\section{Detection of antibodies to extractable nuclear antigens}

As purified antigens are not readily available detection of antibodies has predominantly been by immunodiffusion using saline extracts of various mammalian tissues as the antigen source.

\section{PREPARATION OF TISSUE EXTRACTS}

Apparatus

1 Ultracentrifuge-for example, Beckman, High Wycombe, Buckinghamshire (not needed for commercial rabbit thymus extract);

2 Centrifuge capable of $15000 \mathrm{rpm}$;

3 Tissue homogeniser (a commercial food blender will do);

4 Cold room is ideal but not essential;

5 Dialysis tubing;

6 Ultrafiltration concentrator (with $500 \mathrm{ml}$ capacity)-for example, Millipore (UK) Ltd, Harrow, Middlesex.

\section{Materials and reagents}

1 PBS 0.15M NaCl, 0.01M phosphate pH 7.2.

2 DE 52 ion exchange gel (Pharmacia, Milton Keynes, Buckinghamshire).

3 PBS $0.5 \mathrm{M} \mathrm{NaCl}, 0.01 \mathrm{M}$ phosphate $\mathrm{pH} 7 \cdot 2$.

4 Calf and rabbit thymus extracts are commercially available-for example, PEL-Freez, Denham, Buckinghamshire.

\section{Methods}

(i) Preparation of calf thymus extract (CTE)

Fresh calf thymus can be obtained at most abattoirs and can be stored at $-20^{\circ} \mathrm{C}$ for at least three months before use. About $100 \mathrm{~g}$ of connective tissue should be trimmed and then homogenised in three volumes per weight of PBS in a tissue blender. These procedures should be performed in the cold, preferably in a cold room. After centrifugation at $15000 \mathrm{rpm}$ for 30 minutes at $4^{\circ} \mathrm{C}$ the supernatant is then ultracentrifuged at $35000 \mathrm{rpm}$ for three hours at $4^{\circ} \mathrm{C}$. The supernatant from this spin should then be concentrated to a final protein concentration of $30-40 \mathrm{mg} / \mathrm{ml}$.

(ii) Preparation of human spleen extract (HSE)

The best source of tissue is necropsy spleen which is satisfactory even 48 hours after death. Follow the steps described above, but after ultracentrifugation partial purification using DE52 ion exchange chromatography is required, chiefly to remove the haemoglobin. This is conveniently done in a beaker. Equilibrate $100 \mathrm{~g}$ DE52 gel in PBS. Add extract to gel and stir in the cold for three hours. Centrifuge and discard supernatant. Add $500 \mathrm{ml} 0.5 \mathrm{M}$ $\mathrm{NaCl}, 0.01 \mathrm{M}$ phosphate $\mathrm{pH} 7.2$ and stir for three hours at $4^{\circ} \mathrm{C}$. Centrifuge and concentrate supernatant to a total protein concentration of $30-40 \mathrm{mg} / \mathrm{ml}$ by vacuum ultrafiltration and thoroughly dialyse against PBS.

(iii) Rabbit thymus extract

Dissolve $1.2 \mathrm{~g}$ of commercial rabbit thymus 8 powder in $20 \mathrm{ml}$ PBS and stir at $4^{\circ} \mathrm{C}$ for four hours. After centrifugation at $3000 \mathrm{rpm}$ at $4^{\circ} \mathrm{C}$ for 30 minutes the supernatant is concentrated to about $40 \mathrm{mg}$ protein $/ \mathrm{ml}$.

\section{Notes}

1 The tissue extracts vary in the concentration of different extractable antigens as illustrated in the table.

2 Extracts should be aliquoted in small amounts and kept frozen at $-20^{\circ} \mathrm{C}$ for short term storage (weeks) or at $-70^{\circ} \mathrm{C}$ for long term storage (months). Scl-70, however, is labile and should be freshly made.

3 In addition to RTE, a spleen extract is available from PEL-Freez (Denham, Buckinghamshire) which is a satisfactory source of Ro.

Table Presence of extractable antigens in calf thymus extract (CTE), human spleen extract (HSE), and rabbit thymus extract ( $R T E$ )

\begin{tabular}{|c|c|c|c|c|c|c|c|}
\hline \multirow[b]{2}{*}{ Extract } & \multirow{2}{*}{$\begin{array}{l}\text { Protein } \\
\text { concentration } \\
(\mathrm{mg} / \mathrm{ml})\end{array}$} & \multicolumn{6}{|c|}{ Presence of extractable antigens } \\
\hline & & $U_{1} R N P$ & $S m$ & $\operatorname{Ro}(S S A)$ & $\operatorname{La}(S S B)$ & Scl-70 & Jo-l \\
\hline $\begin{array}{l}\text { CTE } \\
\text { HSE } \\
\text { RTE }\end{array}$ & $\begin{array}{l}30-40 \\
30-40 \\
40\end{array}$ & $\begin{array}{l}++ \\
\pm \\
++\end{array}$ & $\begin{array}{l}+t \\
++ \\
+t\end{array}$ & $\frac{ \pm}{+}+$ & $\begin{array}{l}++ \\
\pm \\
t+\end{array}$ & $\begin{array}{l}0 \\
0 \\
++\end{array}$ & $\begin{array}{l}++ \\
0 \\
\pm\end{array}$ \\
\hline
\end{tabular}


PASSIVE IMMUNODIFFUSION (OUCHTERLONY METHOD)

1 Petri dishes $50 \mathrm{~mm}$ diameter, $20 \mathrm{~mm}$ deep;

2 Gel punch or cork borers (size No 1, diameter $4 \mathrm{~mm}$; size No 4 , diameter $6 \mathrm{~mm}$ );

3 Levelling table;

4 Heated stirring plate;

5 Micropipettes; $20 \mu \mathrm{l}, 100 \mu \mathrm{l}$.

\section{Reagents and materials}

1 PBS containing $0.02 \mathrm{M}$ phosphate, $0.15 \mathrm{M}$ $\mathrm{NaCl}, 0.01 \%$ sodium azide $\mathrm{pH} 7 \cdot 2-7 \cdot 4$.

2 Agarose type 1 (Sigma, Poole, Dorset).

3 Reference sera containing antibodies of known specificity. Initially these can be obtained from the committee on serology of the Arthritis Foundation by writing to: AF-CDC, ANA Reference Laboratory, Immunology Branch, CID, Centers for Disease Control, Atlanta, Georgia 30333, USA. Alternatively, standards are commercially available from the supraregional protein reference unit, Department of Immunology, Royal Hallamshire Hospital, Sheffield. Subsequently, local sera monospecific by Ouchterlony analysis for a particular antibody system can be used as prototype sera.

\section{Methods}

\section{(i) Preparation of Ouchterlony plates}

Make up $0.6 \%$ agarose by stirring agarose powder and buffer on a hot plate. When the mixture is clear the agarose can be stored in bottles at $4^{\circ} \mathrm{C}$. To make plates heat bottles in boiling water until agarose has melted and the solution is clear. Pipette $7 \mathrm{ml}$ into Petri dishes on a levelling table and allow to solidify. Before use the plates should be stored at $4^{\circ} \mathrm{C}$ for at least one hour to allow agarose to "harden".

(ii) Passive immunodiffusion

Cut wells in the agarose with cork borers with a $7 \mathrm{~mm}$ central well surrounded by seven $4 \mathrm{~mm}$ peripheral wells. The distance between the central and peripheral wells should not exceed $3 \mathrm{~mm}$. There is room on the Petri dishes for two sets of wells. Suck out plugs of agarose (this is much easier when plates are cold). Place $20 \mu$ l of serum in the peripheral wells and $100 \mu$ l antigen solution in the centre well. Cover the plates and leave at room temperature. They should be read with the aid of incident light at 24 hours and 48 hours.

\section{Notes}

1 The Ouchterlony technique is one of the simplest and most informative methods. In this procedure antigen and antibody are allowed to diffuse towards each other in a buffered agarose gel and a line of precipitation is formed where the two reactants meet. The precipitate is soluble in excess antigen or antibody, so that a sharp line is produced at equivalence, its relative position being determined by: (i) the concentration of the antigen and antibody in the agar; and (ii) by the molecular weight of the reactants. For these reasons, some sera with high titre antibodies need to be diluted to optimise the line of precipitation. This technique has the advantage that several antigens or sera can be compared around a single well of antibody or antigen.

2 Interpretation: identification of antibody specificity by the pattern of reactions with extracts treated with various enzymes is not recommended.

It should be achieved using prototype sera placed in wells adjacent to the positive test sera (fig 1).

3 Techniques such as passive haemagglutination have been used to detect antibodies to extractable nuclear antigens ${ }^{10}$ but these methods are not recommended unless purified antigen preparations are available. Using immunoaffinity purified antigen, a number of sensitive assays such as ELISA have been developed and will become available in the future.

4 Certain antibodies tend to occur in the same serum. Anti-La-for example, is only very rarely found in the absence of anti-Ro. Antibodies to Ro are accompanied by anti-La in about $50 \%$ of cases. Similarly anti-Sm very often accompanies anti-U1 RNP.

\section{COUNTER IMMUNOELECTROPHORESIS (CIE) \\ Apparatus}

1 Glass plates $80 \mathrm{~mm} \times 80 \mathrm{~mm}$;

2 Electrophoresis tank;

3 Power pack capable of 200 volts (Shandon

Southern, Camberly, Surrey);

4 Cork borer (size No 1; $4 \mathrm{~mm}$ );

5 Humidifying chamber;

6 Levelling table;

7 Heated stirring plate;

8 Template;

9 Micropipettes $(20 \mu \mathrm{l})$. 


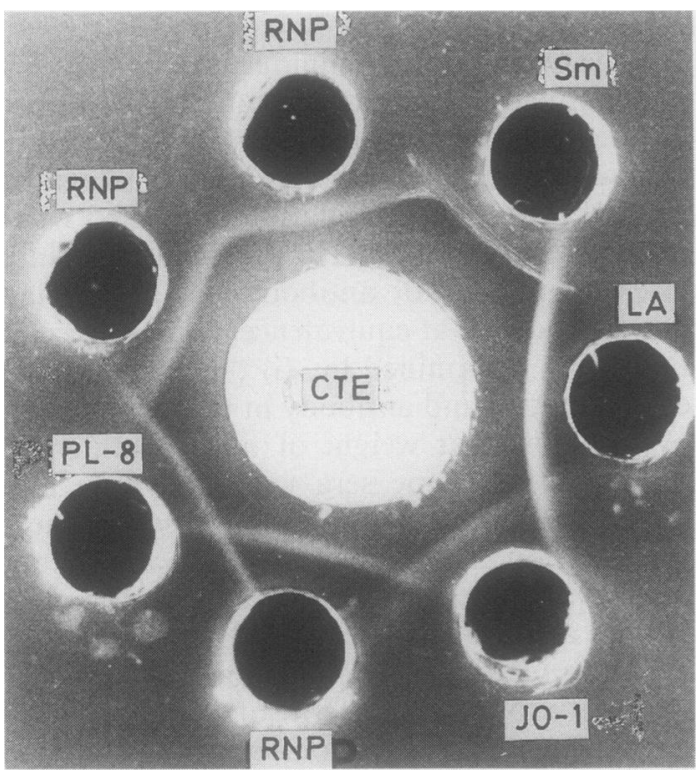

Fig 1 Passive immunodiffusion using the Ouchterlony technique which shows a) reaction of identity shown by fusion of precipitins between two sera containing antibodies to $U I$ $R N P ; b)$ reaction of partial identity shown by spurring of the precipitins between sera containing antibodies UI RNP and $S m$, respectively. This indicates that sera react with different antigens on the same molecular complex, and that one antigen also occurs independently. Both Sm and UI RNP antigenic sites, for example, occur on the same UI ribonucleoprotein particle, while $\mathrm{Sm}$ is also expressed on other nuclear ribonucleoprotein particles; c) reaction of non-identity shown by crossing of the precipitins between the sera containing antibodies to La and those containing anti-Sm and anti-Jo-1.

\section{Materials and reagents}

1 Agarose type 1 (Sigma, Poole, Dorset);

2 Filter paper-for example, Whatmans filter paper No 1;

$30.05 \mathrm{M}$ barbitol buffer $\mathrm{pH} 8 \cdot 2$, sodium barbitone $11.9 \mathrm{~g} ; 1 / 10$ hydrochloric acid $13.75 \mathrm{ml}$; Make up to 1 litre and adjust the $\mathrm{pH}$

\section{Methods}

(i) Preparation of plates:

$80 \mathrm{~mm} \times 80 \mathrm{~mm}$ plates should be stored in $70 \%$ isopropyl alcohol. Prepare $1 \%$ agarose by stirring agarose powder in barbitol buffer on heated plate till dissolved. Aliquots can then be stored for two to three weeks at $4^{\circ} \mathrm{C}$. Pour $12 \mathrm{ml}$ liquid agarose on to glass plates on a levelling table and allow to cool. Allow agarose to "harden" for at least one hour at $4^{\circ} \mathrm{C}$ in a humidity chamber. Using a template (which may consist simply of a paper pattern under the glass plate or a metal template made easily in a machine workshop) and the cork borer, cut two parallel rows of nine $4 \mathrm{~mm}$ wells placed $6 \mathrm{~mm}$ apart horizontally and $2 \mathrm{~mm}$ apart vertically. Remove plugs with suction apparatus.

(ii) Counterimmunoelectrophoresis (CIE):

Fill electrophoresis tank with barbitol buffer, place plates, and use filter paper to make contact between agarose and buffer. Wells should be filled after placing plates in electrophoresis tank and this should be done as soon as possible after cutting the wells.

Firstly, $20 \mu \mathrm{l}$ of prototype or patient sera are added to the anodal column of wells (taking care not to overfill the wells). Plug in the power source and run the plates for 20 minutes at $12.5 \mathrm{~mA}$ per plate. In the second stage $20 \mu \mathrm{l}$ of tissue extract are added to the cathodal wells (with the power off) and the plates are run for a further 60 minutes. The plates are then read immediately at one hour and at 24 hours.

Notes

1 Numerous methods for CIE have been described and are reviewed by McCarty et al. ${ }^{11}$ 2 CIE can detect about $20 \mu \mathrm{g} / \mathrm{ml}$ of specific antibody and is about five times more sensitive than passive immunodiffusion. Identification of individual precipitin lines can be more difficult. Lines can be made clearer by washing the slides for several days in $5 \%$ sodium citrate.

3 Definition of antibody specificity depends on noting a reaction of identity with a prototype serum (fig 2). This can be facilitated by reducing the vertical distance between the wells to $1 \mathrm{~mm}$, staggering the serum and tissue extract wells or by cutting a trough for the extract.

$40.01 \%$ sodium azide can be added to the agarose to retard bacterial growth but this may necessitate changes in the conditions of electrophoresis because of the charge changes relative to the sodium azide.

5 We use CIE as a screening test and confirm the identity of precipitins by the Ouchterlony technique. Other laboratories, however, depend entirely on CIE.

6 An External Quality Assessment Scheme for ENA antibodies exists. (Organiser, Dr Milford Ward, protein reference unit, immunology 


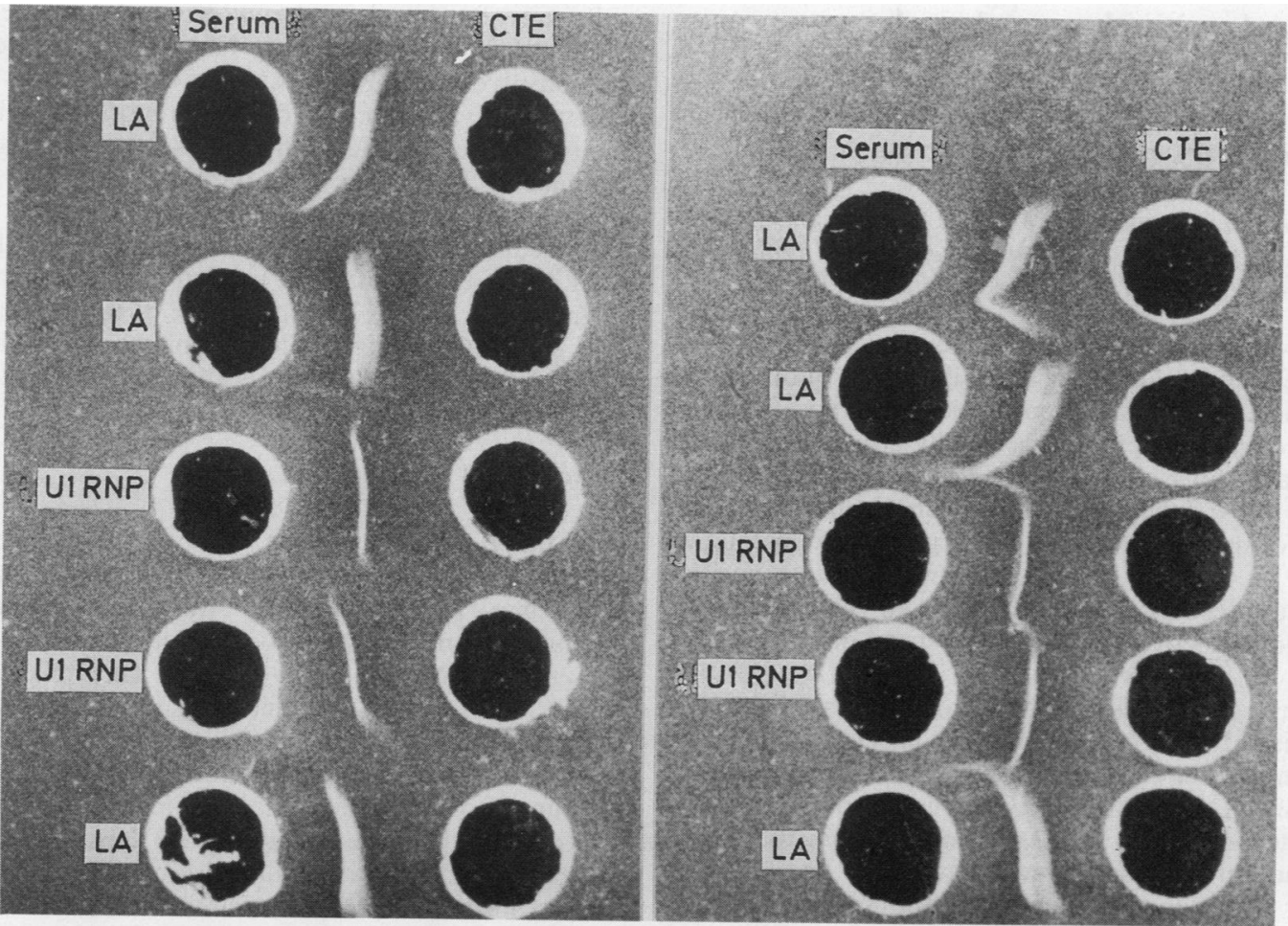

Fig 2 Counter immunoelectrophoresis. This shows that reactions of identity can be aided by reducing the vertical distance between the wells to $1 \mathrm{~mm}$. This can also be achieved by staggering the serum and antigen wells or by cutting a trough for the antigen.

department, Royal Hallamshire Hospital, Sheffield).

Bloomsbury Rheumatology Unit, University College and the Middlesex Hospital Medical School,

London

PJ MADDISON Royal National Hospital for Rheumatic Diseases, Bath

\section{References}

I Johnson GD, Holborow EJ. Routine Immunofluorescent test for serum antinuclear antibodies. $A C P$ Broadsheet 107. London: ACP/BMA, 1983.

2 Schwartz RS, Stollar BD. Origins of anti-DNA antibodies. J Clin Invest 1985;75:321-7.

3 Stollar BD. Anti-DNA antibodies. In: Fauci AS, ed. Clinics in Immunology and Allergy. Vol 1. London: WB Saunders Co, 1981:243-60.

4 Hardin JA, Mimori T. Autoantibodies to ribonucleoproteins. Clin Rheum Dis 1985; 11:485-505.

5 Shero JM, Bordwell B, Rothfield NF, Earnshaw WC. High titres of autoantibodies to Topoisomerase 1 (Scl$70)$ in sera from scleroderma patients. Sciences 1986;231:737-40.
6 Reichlin M. Current perspectives on serological reactions in SLE patients. Clin Exp Immunol 1981;44:1-8.

7 Farr RS. A quantitative immunochemical measure of the primary interaction between I-BSA and antibody. $J$ Infect Dis 1958;103:239-62.

8 Isenberg DA, Dudeney C, Williams W, et al. Measurement of anti-DNA antibodies: A reappraisal using five different methods. Ann Rheum Dis 1987; 46:448-56.

9 Somerfield SD, Roberts MW, Booth RJ. Double stranded DNA antibodies: a comparison of four methods of detection. J Clin Pathol 1981;34:1032-5.

10 Sharp GC, Irvin WS, La Roque RC, Velez C, Daly V, Kaiser AD, Holman HR. Association of autoantibodies to different nuclear antigens with clinical patterns of rheumatic disease and responsiveness to therapy. J Clin Invest 1971;50:350-9

11 McCarty GA, Valencia DW, Fritzler MJ. Antinuclear antibodies. Contemporary techniques and clinical application to connective tissue diseases. New York: Oxford University Press, 1984.

This Broadsheet has been prepared by the authors at the invitation of the Committee on Technical Methods. Copyright reserved by the Association of Clinical Pathologists. Further copies of this Broadsheet may be obtained from the Publishing Manager, Journal of Clinical Pathology, BMA House, Tavistock Square, WCIH 9JR.

ISSN: 03082555 